\title{
Strategi Pengelolaan Sumberdaya Pesisir Di Kabupaten Buleleng
}

\author{
I Putu Ananda Citra ${ }^{1 *}$ \\ ${ }^{1}$ Jurusan Pendidikan Geografi, Undiksha, Singaraja, Indonesia
}

\section{A R T I C L E IN F O}

Article history:

Received 31 Oktober 2018

Accepted 30 November 2018

Available online 31

Desember 2018

\section{Kata Kunci:}

Potensi Sumberdaya Pesisir; Pemberdayaan Masyarakat; Wilayah

Pesisir

Keywords:

Potential Coastal

Resources; Community

Empowerment; Coastal Region

\begin{abstract}
A B S T R A K
Penelitian ini dilaksanakan di wilayah pesisir Kabupaten Buleleng dengan tujuan 1) mendeskripsikan potensi sumberdaya pesisir, 2) Menganalisis strategi pemberdayaan masyarakat untuk pengelolaan sumberdaya pesisir Kabupaten Buleleng. Metode yang digunakan dalam penelitian ini adalah survai didukung dengan metode observasi. Pengambilan sampel dengan teknik purposive sampling. Analisis data dilakukan dengan teknik analisis deskriptifkualitatif dan analisis SWOT. Hasil penelitian menunjukkan, 1) Sumberdaya pesisir di Kabupaten Buleleng yang meliputi: (1) sumberdaya hayati yaitu potensi perikanan dan terumbu karang, (2) sumberdaya buatan yaitu dermaga dan (3) sumberdaya jasa-jasa lingkungan yaitu keindahan terumbu karang, atraksi lumba-lumba dan pemandangan sunset sebagai potensi ekowisata. 2) Strategi pengembangan sumberdaya pesisiruntuk pemberdayaan masyarakat pembudidayaan ikan, pelestarian terumbu karang, pelatihan peningkatan pelayanan wisata, penyediaantempat pelelangan ikan, pengadaan modal dan kerjasama bagi usaha-usaha masyarakat dalam membuat kerajinan tangan, penegakan hukum atau awig-awig beserta sanksi, memberikan batasan masuknya produk perikanan dari luar daerah.
\end{abstract}

A B S T R A C T

This research was carried out in the coastal area of Buleleng Regency with the aim of 1) describing the potential of coastal resources, 2) Analyzing community empowerment strategies for the management of coastal resources of Buleleng Regency. The method used in this study is a survey supported by observation methods. Sampling with purposive sampling technique. Data analysis was carried out with descriptive qualitative analysis techniques and SWOT analysis. The results showed, 1) Coastal resources in Buleleng Regency which included: (1) biological resources namely fisheries and coral reefs potential, (2) artificial resources namely docks and (3) environmental services resources namely the beauty of coral reefs, lumba attractions dolphins and sunset views as a potential ecotourism. 2) Strategy for developing coastal resources for community empowerment of fish cultivation, coral reef conservation, training in improving tourism services, providing fish auction places, providing capital and cooperation for community efforts in making handicrafts, law enforcement or awig-awig along with sanctions, limiting entry fishery products from outside the region. 



\section{Pendahuluan}

Potensi ekologis sumberdaya pesisir dapat didefinisikan peran pesisir sebagai pengatur keseimbangan lingkungan, keseimbangan iklim, dan keseimbangan panas bumi. Sementara potensi pendidikan wilayah pesisir dapat diartikan bahwa wilayah pesisir memiliki peran sebagai media pembelajaran dan kegiatan riset (Mahfud, 2009: 82). Sumberdaya pesisir merupakan aset yang sangat besar dan menjanjikan untuk masa depan. Sumberdaya pesisir saat ini sudah semakin disadari banyak orang bahwa sumberdaya pesisir merupakan suatu potensi yang sangat menjanjikan dalam mendukung perekonomian masyarakat terutama masyarakat yang bekerja terkait dengan potensi pesisir tersebut. Pemanfaatan sumberdaya pesisir di setiap wilayah mengalami peningkatan, namun pengelolaan sumberdaya pesisir masih jauh dari tingkat optimal dan berkelanjutan. Banyak faktor menyebabkan pengelolaan sumberdaya pesisir tidak optimal dan berkelanjutan, berkenaan dengan itu pengelolaannya menjadi penting sehingga dapat berkembang secara optimal. Pengelolaan sumberdaya pesisir harus dilakukan secara terencana dan terpadu. Pengelolaan sumberdaya pesisir secara terpadu adalah suatu proses untuk mewujudkan pembangunan kawasan pesisir secara optimal dan berkelanjutan (Dahuri, dkk, 1996: 180). Apabila perencanaan dan pengelolaan sumberdaya pesisir dan lautan tidak dilakukan secara terpadu, maka dikhawatirkan sumberdaya tersebut akan rusak bahkan punah, sehingga tidak dapat dimanfaatkan untuk menopang kesinambungan pembangunan nasional dalam mewujudkan bangsa yang maju, adil dan makmur.

Pengelolaan sumberdaya sebenarnya telah ditetapkan dalam Pasal 33 Undang-Undang Dasar 1945 yang menyebutkan bahwa bumi dan air dan kekayaan alam yang terkandung di dalamnya dikuasai oleh Negara dan dipergunakan sebesar-besarnya bagi kemakmuran rakyat. Ketentuan tersebut secara tegas menginginkan agar pelaksanaan penguasaan Negara atas sumberdaya alam khususnya sumber daya pesisir dan lautan diarahkan kepada tercapainya manfaat yang sebesar-besarnya bagi kemakmuran rakyat, dan juga harus mampu mewujudkan keadilan dan pemerataan sekaligus memperbaiki kehidupan masyarakat pesisir. Implementasi yuridis pengelolaan sumberdaya pesisir berbasis wilayah pesisir secara terpadu memiliki regulasi sebagai pedoman dalam berbagai program yang mengupayakan kesejahteraan masyarakat pesisir khususnya nelayan terutama nelayan tradisonal/skala kecil di Kota Cirebon (Sutrino, 2014). Demikian dengan Pulau Bali merupakan salah satu pulau yang sebagian besar wilayahnya merupakan kawasan pesisir. Kawasan pesisir di Pulau Bali telah dimanfaatkan dengan berbagai kegiatan salah satunya kegiatan pariwisata, baik itu kawasan pesisir Bali selatan maupun Bali Utara. kesenjangan perkembangan pariwisata di Provinsi Bali masih tetap terjadi yaitu antara Bali bagian utara dengan Bali bagian selatan. Pariwisata seolah putus aktivitasnya di bagian utara Pulau Bali yaitu di Kabupaten Buleleng. Pesatnya perkembangan pariwisata khususnya wisata pantai di Bali bagian selatan seperti Pantai Kuta dan Sanur hampir tidak terjadi pada pesisir Buleleng (Citra, 2015:3). Padahal Kabupaten Buleleng memiliki pantai terpanjang di Bali yaitu 157,05 Km (http://Bulelengkab.go.id). Hal ini berarti bahwa potensi yang dimiliki khususnya potensi sumberdaya pesisir sangat besar untuk dikembangkan seperti yang terdapat pada Kawasan Lovina. Informasi dalam pengelolaan sumberdaya pesisir yang sudah dimanfaatkan maupun yang belum dikelola, sangat penting untuk diketahui sebagai dasar dalam merumuskan strategi pengelolaan sumberdaya pesisir.

\section{Metode}

Penelitian ini dilakukan di wilayah pesisir Kabupaten Buleleng.Pengambilan sampel wilayah dilakukan secara purposive area sampling, karena objek wisata yang berada di wilayah pesisir Kabupaten Buleleng tersebar dari daerah pesisir bagian timur sampai barat. Pembagian 3 zone wilayah Kabupaten Buleleng dijadikan dasar dalam pengambilan sampel objek wisata, yaitu sampel objek wisata yang berada di wilayah pesisir timur (Air Sanih), pesisir tengah (Lovina), dan pesisir barat (Desa Pemuteran). Pengambilan sampel masyarakat dilakukan secara purposive pada area sample yang sudah ditentukan yaitu masyarakat pesisir yang dapat memenuhi syarat atau mewakili untuk kepentingan penelitian, serta mewakili kelengkapan unsur-unsur yang akan diamati dan dinilai berkaitan dengan kegiatan pariwisata di Kabupaten Buleleng. 
Data yang dikumpulkan yaitu dengan cara observasi, wawancara, kuisioner dan kajian pustaka. Selanjutnya pengolahan data dengan analisis kualitatif pada masing-masing indikator untuk dapat mendeskripsikan potensi sumberdaya pesisir dan Analisis SWOT digunakan untuk merumuskan rencana strategis dalam pemberdayaan masyarakat di wilayah pesisir.

\section{Hasil dan pembahasan}

\subsection{Potensi Sumberdaya Pesisir di Wilayah Kabupaten Buleleng}

Luasnya wilayah pesisir di Kabupaten Buleleng memerlukan teknik untuk menggali informasi sehingga dapat mencerminkan keseluruhan potensi terutama potensi sumberdaya pesisir. Bentuk wilayah yang sempit dan memanjang dari timur ke barat dengan karakteristik topografi pantai yang berbeda, maka diperlukan pembagian zone berdasarkan karakteristiknya tersebut. Pembagian tiga zone dan analisis masing-masing potensi sudah dapat menggambarkan potensi sumberdaya pesisir di Kabupaten Buleleng sehingga dapat menyusun strategi pemberdayaan masyarakat wilayah pesisir. adapun potensi sumberdaya pesisir di Kabupaten Buleleng yaitu sebagai berikut.

1) Sumberdaya Hayati

1) Sumberdaya ikan

Wilayah pesisir Kabupaten Buleleng memiliki potensi sumberdaya ikan yang melimpah. Ikan merupakan potensi sumberdaya pesisir utama bagi masyarakat pesisir. Kabupaten Buleleng yang sebagian wilayahnya merupakan wilayah pesisir, tidak menghapus tradisi masyarakatnya sebagai nelayan. Keadaan geografis yang berupa dataran rendah pinggir laut menyebabkan masyarakat di Kabupaten Buleleng berprofesi sebagai nelayan untuk memenuhi kebutuhan hidup sehari-hari. Menurut ketua kelompok nelayan Desa Pemaron (Ariasa), Kalibukbuk (Made Budiasa) dan Temukus (Ketut Sarka) pada sektor perikanan tangkap, Kabupaten Buleleng memiliki komoditi perikanan tangkap seperti ikan dan cumi-cumi. Jenis-jenis ikan yang biasa ditangkap oleh nelayan di Kabupaten Buleleng adalah ikan jenis kerapu, kakap dan tongkol, tuna karena jenis ikan tersebut banyak terdapat di perairan Bali Utara. Selain ikan, hasil tangkapan lainnya adalah cumicumi ukuran kecil. Para nelayan biasa mengakap ikan selama 7-8 jam dalam sekali melaut dengan hasil tangkapan ikan sebanyak 50 hingga 90 kilogram. Armada penangkapan ikan yang digunakan nelayan di Kabupaten Buleleng digolongkan atas tiga jenis yaitu tanpa perahu, perahu tanpa motor dan perahu motor. Penangkapan ikan oleh nelayan dengan armada perahu tanpa motor maupun tanpa perahu dilakukan di perairan dangkal, sedangkan penangkapan ikan dengan armada perahu motor dilakukan di perairan yang lebih dalam sejauh $24-40$ mil. Selain itu alat penangkapan ikan yang digunakan oleh nelayan di Kabupaten Buleleng masih tergolong tradisional atau sederhana yaitu pancing dan jaring.

2) Potensi terumbu karang

Terumbu karang merupakan salah satu kekayaan alam yang bernilai tinggi. Manfaat yang terkandung di dalam ekosistem terumbu karang sangat besar dan beragam, baik manfaat langsung maupun manfaat tidak langsung. Wilayah pesisir Kabupaten Buleleng memiliki sebaran terumbu karang yang cukup panjang. Ekosistem terumbu karang di Kabupaten Buleleng berada kurang lebih 50 meter dari garis pantai, sepanjang pantai Desa Pemaron, Tukadmungga, Anturan, Kalibukbuk, Kaliasem dan Temukus. Terumbu karang yang terdapat di Kabupaten Buleleng memiliki luas penyebaran sebesar 1,5 km2 (Jurnal Sains dan Teknologi 2012). Terumbu karang di Kabupaten Buleleng secara umum dikategorikan sebagai terumbu karang tepi (fringing reefs) yang merupakan terumbu karang yang hidup disepanjang pantai, meskipun di beberapa titik pengamatan ditemukan tipe terumbu karang penghalang (barrier reef) yang berupa atol. Terumbu karang mempunyai fungsi dan manfaat serta arti yang sangat penting bagi kehidupan masyarakat pesisir di Kabupaten Buleleng baik dari segi ekologi, ekonomi dan penunjang pariwisata. Secara ekologi terumbu karang memiliki manfaat yaitu (1) secara langsung terumbu karang menjadi penunjang kehidupan berbagai jenis makhluk hidup yang ada 
di sekitarnya sebagai tempat tinggal, mencari makan dan berkembang biak bagi biota laut, (2) terumbu karang mampu memperkecil energi ombak yang menuju ke daratan, sehingga mencegah terjadinya abrasi pantai. Terumbu karang secara langsung maupun tidak langsung menjadi sumber ekonomi bagi masyarakat. Keberadaan terumbu karang menunjang perekonomian masyarakat pesisir di Kabupaten Buleleng. Pengembangan terumbu karang menjadi objek wisata mampu menciptakan berbagai lapangan pekerjaan bagi masyarakat di Kabupaten Buleleng.

2) Jasa-Jasa Lingkungan

Pariwisata alam merupakan sektor yang potensial untuk dikembangkan. Wisata Bahari adalah salah satu wisata andalan Kabupaten Buleleng dengan menyuguhkan pesona keindahan alam yang terletak diantara pegunungan dan laut. Kabupaten Buleleng menyediakan beranekaragam sumberdaya laut yang biasanya diasosiasikan dengan tiga " $\mathrm{S}$ " (sun, sea and sand). Jenis layanan wisata bahari yang terdapat di Kabupaten Buleleng adalah mengamati atraksi lumba-lumba, memancing, diving, dan snorkeling. Lumba-lumba yang terdapat di Kabupaten Buleleng tepatnya di Lovina merupakan salah satu potensi yang memiliki daya tarik tersendiri bagi wisatawan domestik maupun mancanegara. Wisatawan yang ingin melihat atraksi lumba-lumba harus melakukan perjalan pagi-pagi karena lumbalumba di kawasan ini hanya muncul antara pukul 6 hingga pukul 8 pagi. Pada jam tersebut, puluhan lumba-lumba akan beratraksi secara alami menunjukkan kegiatan mereka, ada yang sekedar berenang di permukaan air dan ada juga yang melompat-lompat.

Keindahan alam yang terdapat di Kabupaten Buleleng tidak hanya di sekeliling pantainya saja tetapi juga yang berada di dalam air dengan cara melakukan diving ataupun snorkeling. Ada beranekaragan ikan hias dan terumbu karang yang dapat dilihat di dalam laut bila wisatawan diving di spot bagian taman lautnya. Hal ini lebih banyak terdapat di Desa Pemuteran dengan budidaya terumbu karang yang dikenal dengan Biorock menjadi daya tarik wisata utama dapat dilihat pada Gambar 3. Selain dapat melihat pemandangan pantai dan lautan, wisatawan juga dapat melihat pemandangan gunung jika mengahadap kearah selatan. Banyak kegiatan yang dapat dilakukan oleh para wisatawan saat berkunjung yaitu berjalan-jalan di sepanjang pesisir pantai sambil menikmati pemandangan alam yang indah dan dapat berfoto serta menikmati indahnya matahari terbenam (sunset).

Di Kawasan pesisir khususnya di Pantai Lovina juga berkembang fasilitas-fasilitas penunjang pariwisata atau akomodasi selama kegiatan kepariwisataan berlangsung, seperti penginapan mulai dari homestay hingga hotel berbintang, rumah makan, dan bagi wisatawan yang ingin melakukan penyelaman atau ingin berkeliling menaiki perahu atau dalam bahasa lokal disebut jukung. Selain itu pengelola wisata pantai Lovina juga sudah menyediakan fasilitas-fasilitas lain seperti toko souvenir, pos keamanan, klinik kesehatan, pusat informasi, toilet umum dan tempat ibadah.

3) Sumberdaya Buatan

Sumberdaya buatan yaitu potensi yang dapat mendukung kegiatan di wilayah pesisir Buleleng yang dibuat oleh manuasia atau masyarakat sekitar. adapun sumberdaya buatan yag terdapat di wilayah pesisir yaitu dermaga Pantai Lovina merupakan aset Kementerian Pariwisata dan Ekonomi Kreatif Republik Indonesia dan satu dari sembilan jenis bangunan yang ada di wilayah objek wisata Lovina. Tujuan awal pembangunan Dermaga Pantai Lovina ini adalah untuk bersandarnya kapal Gross Tonage dan untuk bersandarnya perahu jukung nelayan wisata pengantar wisatawan menyaksikan lumba-lumba. Pemandian umum Air sanih di Desa Bukti yang dijadikan daya tarik pariwisata. Kabupaten Buleleng sudah dikenal di dunia Internasional, dermaga Pantai Lovina ini akan dikembangkan menjadi dermaga kapal pesiar sebagai tempat bersandarnya kapal pesiar dari berbagai negara. Pengembangan dermaga tersebut akan memberikan akses lebih kepada para wisatawan yang berkunjung ke Kawasan Pantai Lovina. Pembangunan Dermaga Pantai Lovina bertaraf Internasional akan mempengaruhi peningkatan kunjungan wisatawan ke wilayah Bali Utara. Sehingga akan meningkatkan pembangunan daerah di bidang pariwisata. 


\subsection{Strategi Pengelolaan Sumberdaya Pesisir untuk Pemberdayaan Masyarakat Wilayah Pesisir Kabupaten Buleleng}

Dalam pemanfaatan sumberdaya pesisir tentunya tidak terlepas dari berbagai kendala, untuk meminimalisir kendala tersebut perlu adanya strategi dalam pengelolaan potensi sumberdaya pesisir. Potensi sumberdaya pesisir oleh masyarakat di Kabupaten Buleleng telah lama diketahui dan juga disadari bahwa potensi sumberdaya pesisir yang ada memiliki berbagai macam manfaat baik langsung maupun tidak langsung bagi kehidupan masyarakat setempat. Pengelolaan sumberdaya pesisir di Kabupaten Buleleng, secara umum akan dipengaruhi oleh lingkungan strategis wilayahnya, baik lingkungan internal maupun eksternal, yang dapat menentukan tingkat keberhasilan pemanfaatan dan pengambangannya. Untuk lingkungan internal secara sinergis akan menentukan kekuatan (strengths) dan kelemahan (weaknesses) masyarakat, pengelola wisata dan pemerintah dalam menyikapi permasalahan yang ada maupun yang akan datang dalam pengelolaan sumberdaya pesisir. Lingkungan eksternal akan menentukan peluang (opportunities) dan ancaman (threatst) yang akan dihadapi oleh pemerintah, masyarakat, dan pengelola wisata dalam mengelola sumberdaya pesisir. Rencana strategis dalam pengelolaan sumberdaya pesisir dirangkum dalam matrik SWOT. Hasil strategi alternatif untuk pengelolaan sumberdaya pesisir dapat dilihat pada Tabel 1.

Tabel 1. Strategi Alternatif Kombinasi SO, WO, ST, dan WT

\begin{tabular}{|c|c|c|}
\hline Internal & $\begin{array}{l}\quad \text { Opportunities (0) } \\
\text { 1. Permintaan ikan tinggi } \\
\text { 2. Populasi ikan karang } \\
\text { 3. Jumlah wisatawan meningkat } \\
\text { 4. Permintaan Garam Tinggi }\end{array}$ & $\begin{array}{l}\text { Threats (T) } \\
\text { 1. Masuknya produk perikanan dari luar } \\
\text { daerah } \\
\text { 2. Eksploitasi terumbu karang } \\
\text { 3. Persaingan pariwisata cukup tinggi } \\
\text { 4. Cuaca buruk }\end{array}$ \\
\hline $\begin{array}{l}\text { Strengths (S) } \\
\text { 1. Potensi ikan } \\
\text { 2. Potensi terumbu } \\
\text { karang } \\
\text { 3. Memiliki daya tarik } \\
\text { wisata } \\
\text { 4. Lingkungan sekitar } \\
\text { pantai asri dan } \\
\text { nyaman }\end{array}$ & $\begin{array}{l}\quad \text { Strategi S-O } \\
\text { 1. Pembudidayaan ikan } \\
\text { 2. Pelestarian terumbu } \\
\text { karang } \\
\text { 3. Pelatihan peningkatan } \\
\text { pelayanan wisata } \\
\text { 4. Pemeliharaan lingkungan } \\
\text { sekitar pantai agar tetap } \\
\text { asri dan nyaman }\end{array}$ & $\begin{array}{l}\text { Strategi S-T } \\
\text { 1. Menambah produk perikanan dalam } \\
\text { daerah } \\
\text { 2. Penegakan hukum atau awig-awig } \\
\text { beserta sanski } \\
\text { 3. Menjaga potensi wisata dengan baik } \\
\text { 4. Meningkatkan kesadaran } \\
\text { masyarakat untuk menjaga } \\
\text { lingkungan sekitar pantai }\end{array}$ \\
\hline $\begin{array}{l}\text { Weaknesses (W) } \\
\text { 1. Belum adanya pasar } \\
\text { khusus untuk } \\
\text { menjual ikan } \\
\text { 2. Rendahnya kualitas } \\
\text { SDM masyarakat } \\
\text { lokal dalam } \\
\text { pengelolaan } \\
\text { terumbu karang } \\
\text { 3. Usaha produk } \\
\text { kerajinan tangan } \\
\text { masih rendah } \\
\text { 4. Rendahnya } \\
\text { keterampilan } \\
\text { Masyarakat } \\
\text { produksi garam }\end{array}$ & \begin{tabular}{l}
\multicolumn{1}{c}{ Strategi W-o } \\
1. Penyediaan tempat \\
pelelangan ikan \\
2. Memberikan pelatihan \\
kepada masyarakat tentang \\
pelestarian terumbu karang \\
3. Pengadaan modal bagi \\
usaha-usaha masyarakat \\
dalam membuat kerajinan \\
tangan \\
4. Meningkatkan Produksi \\
Garam dapur
\end{tabular} & $\begin{array}{l}\text { Strategi W-T } \\
\text { 1. Memberikan batasan masuknya } \\
\text { produk perikanan dari luar daerah. } \\
\text { 2. Meningkatkan kesadaran } \\
\text { masyarakat tentang pentingnya } \\
\text { menjaga sumberdaya terumbu } \\
\text { karang } \\
\text { 3. Menjalin kerja sama dengan } \\
\text { kalangan swasta dan pemerintah } \\
\text { dalam meningkatkan produk } \\
\text { kerajinan tangan } \\
\text { 4. Melatih masyarakat pembuatan } \\
\text { garam dengan teknik rumah kaca }\end{array}$ \\
\hline
\end{tabular}


Dalam pengelolaan sumberdaya pesisir di Kabupaten Buleleng perlu adanya strategi. Perumusan rencana strategi pengelolaan sumberdaya pesisir di Kabupaten Buleleng dilakukan dengan menggunakan analisis SWOT dengan menganalisis faktor-faktor internal dan eksternal yang terdapat di Kabupaten Buleleng. Strategi pengelolaan potensi sumberdaya pesisir di Kabupaten Buleleng berdasarkan tabel 1 dengan analisis SWOT dijelaskan adalah sebagai berikut.

1) Strategi Kekuatan-Kesempatan (S dan 0)

1) Pembudidaayan ikan.

Pembudidayaan ikan akan nilai tambah terhadap pendapatan masyarakat yang bekerja terkait dengan sumberdaya pesisir yang terdapat di Kabupaten Buleleng.

2) Pelestarian terumbu karang.

Pelestarian terumbu karang dilakukan dengan tujuan untuk menjaga ekosistem terumbu karang dari kerusakan akibat faktor alam maupaun manusia.

3) Pelatihan peningkatan pelayanan wisata.

Tujuan pelatihan peningkatan pelayanan wisata adalah untuk meningkatkan kemampuan dan keterampilan masyarakat yang bekerja di sektor pariwisata.

4) Pemeliharaan lingkungan pantai agar tetap asri dan nyaman.

Pemeliharan lingkungan pantai di Kabupaten Buleleng merupakan salah satu upaya untuk memberikan kenyamanan bagi setiap pengunjungnya. Sehingga dengan lingkungan yang asri dan nyaman dapat meningkatkan jumlah kunjungan wisatawan.

2) Strategi Kelemahan-Kesempatan (W dan O)

1) Penyediaan tempat pelelangan ikan.

Dengan tersedianya tempat pelelangan ikan akan memudahkan para nelayan memasarkan hasil tangkapannya.

2) Memberikan pelatihan kepada masyarakat tentang pelestarian terumbu karang. Tujuan pemberian pelatihan ini guna meningkatkan pengetahuan dan keterampilan masyarakat untuk melestarikan terumbu karang yang ramah.

3) Pengadaan modal bagi usaha-usaha masyarakat dalam membuat kerajinan tangan. Tujuan pengadaan modal tersebut adalah untuk meningkatkan kualitas kerajinan tangan yang dibuat oleh masyarakat lokal setempat.

3) Strategi Kekuatan-Ancaman (S dan T)

1) Menambah produk perikanan dalam daerah tujuannya adalah untuk dapat memenuhi permintaan ikan yang tinggi.

2) Penegakan hukum atau awig-awig beserta sanksiadalah untuk memberikan sanksi terhadap oknum yang melakukan ekspoitasi terumbu karang.

3) Menjaga potensi wisata bertujuan untuk mempertahankan kekhasan wisata yang dimiliki.

4) Meningkatkan kesadaran masyarakat untuk menjaga lingkungan sekitar pantai. Kesadaran masyarakat terhadap lingkungan ini bertujuan agar lingkungan sekiar pantai tetap bersih sehingga dapat memberikan kenyamanan bagi setiap pengunjung.

4) Strategi Kelemahan-Ancaman (W dan T)

1) Memberikan batasan masuknya produk perikanan dari luar daerah. Pembatasan ini bertujuan untuk lebih mengutamakan produk perikanan dalam daerah.

2) Meningkatkan kesadaran masyarakat tentang pentingnya menjaga sumberdaya terumbu. Kesadaran masyarakat terhadap ekosistem terumbu karang sangat penting karena terumbu karang memberikan berbagai manfaat untuk biota laut dan masyarakat itu sendiri.

3) Menjalin kerja sama dengan kalangan swasta dan pemerintah dalam meningkatkan produk kerajinan tangan.adanya kerjasama dengan pihak swasta dan pemerintah dapat meningkatkan produk kerajianan tangan dalam skala besar Startegi pengelolaan sumberdaya pesisir Kabupaten Buleleng antaranya pembudidayaan ikan, pelestarian terumbu karang, pelatihan peningkatan pelayanan wisata, pemeliharaan lingkungan pantai agar tetap asri dan nyaman, penyediaan fasilitas tempat pelelangan ikan, memberikan pelatihan kepada masyarakat tentang pelestarian terumbu karang, 
pengadaan modal bagi usaha-usaha masyarakat dalam membuat kerajinan tangan, menambah produk perikanan dalam daerah, penegakan hukum atau awig-awig beserta sanski, menjaga potensi wisata dengan baik, meningkatkan kesadaran masyarakat untuk menjaga lingkungan sekitar pantai, memberikan batasan masuknya produk perikanan dari luar daerah, meningkatkan kesadaran masyarakat tentang pentingnya menjaga sumberdaya terumbu, menjalin kerja sama dengan kalangan swasta dan pemerintah dalam meningkatkan produk kerajinan tangan.

\section{Simpulan dan saran}

Berdasarkan hasil dan pembahasan dari tujuan penelitian, dapat ditarik kesimpulan sebagai berikut. Pertama, potensi sumberdaya pesisir yang berada di wilayah pesisir Kabupaten Buleleng secara umum beraneka ragam. Seperti perikanan, budidaya terumbu karang, dan pemanfaatan di bidang pariwisata. Potensi yang belum di lakukan adalah budidaya ikan. Kedua, strategi pemberdayaan masyarakat pesisir sangat penting untuk dibuat dan dilakasanakan. Nelayan hanya baru sebatas menangkap saja. Perlunya pemberdayaan masyarakat dalam pembudidayaan perikanan. Di bidang pariwisata strategi yang bisa dikembangkan yaitu di pada kerajinan cendera mata karena barang-barang souvenir didatangkan dari luar desa bahkan kabupaten. Adapun rekomendasi adalah sebagai berikut. Pertama, bagi Pemerintah Kabupaten Buleleng dalam rangka pembangunan wilayah khususnya wilayah pesisir agar mulai untuk berorietasi pada pemberdayaan masyarakat pesisir di Kabupaten. Kedua, bagi Desa Adat agar menjadikan awig-awig desa sebagai bingkai kegiatan pariwisata. Terakhir, bagi masyarakat pesisir agar lebih memanfaatkan peluang usaha berdasarkan potensi sumberdaya pesisir yang dimiliki.

\section{Daftar Rujukan}

Baiquni, M. 2010. Pariwisata Berkelanjutan dalam Pusaran Krisis Global. Denpasar: Udayana University Press.

Efendi, Sofian dan Singarimbun, Masri. 1987. Metode Penelitian Survai. Yogyakarta: LP3ES

Pendit. 2002. Ilmu Pariwisata Sebuah Pengantar Perdana. Jakarta: Pradnya Paramitha.

Rangkuti, Frenddy. 2004. Analisis SWOT Teknik Membedah Kasus Bisnis. Jakarta: PT Gramedia Pustaka Utama.

Sutrisno, Endang, 2014. Implementasi pengelolaan Sumberdaya Pesisir Berbasis Pengelolaan wilayah Pesisir Secara Terpadu Untuk Kesejahteraan Nelayan (Studi di Perdesaan Nelayan Cangkol Kelurahan Lemahwungkuk Kecamatan Lemahwungkuk Kota Cirebon). Jurnal Dinamika Hukum, 14(1).

Western, David. 1995. Ekoturisme: Petunjuk Untuk Perencanaan \& Pengelolaan. Jakarta: The Ecotourism Society North Benington, Vermont.

http://www.bulelengkab.go.id/index.php/pariwisata/19/Wisata-Alam Diakses tanggal 15 April 2018

Undang-Undang Republik Indonesia Nomer 1 Tahun 2014 tentang Pengelolaan Wilayah Pesisir dan Pulau-Pulau Kecil. 